\title{
Morphological Development of Egg, Larvae and Juvenile in Korean shinner, Coreoleuciscus splendidus from the Ungcheon-Stream of Korea
}

\author{
Jae-Min Park ${ }^{1}$, Seong-Jang Cho², Hye-In Jo ${ }^{1}$, and ${ }^{\dagger}$ Kyeong-Ho Han ${ }^{3}$ \\ ${ }^{1}$ Gyeongsangbuk-Do Native Fish Business Center, Uieseong 37366, Korea \\ ${ }^{2}$ Boryeong Freshwater Eco Center, Boryeong 33416, Korea \\ ${ }^{3}$ Marine Technology Undergraduate, Chonnam National University, Yeosu 59626, Korea
}

\begin{abstract}
The purpose of this study is to investigate the development of Coreoleuciscus splendidus egg and larvae morphology in the Ungcheon-stream. C. splendidus eggs were round and ranged in size from 1.86-2.01 mm (mean $1.91 \pm 0.14$ $\mathrm{mm}$ ). Immediately after hatching, the larvae had egg yolk in the abdomen with a total length of 5.27-6.63 mm (mean $5.95 \pm 0.96 \mathrm{~mm}$ ). On the 10 days after hatching, the latter was $8.44-8.65 \mathrm{~mm}$ (mean $8.54 \pm 0.14 \mathrm{~mm}$ ) in total length, and 5 dorsal fin rays were formed in dorsal fin and 8 caudal fin soft rays were formed in caudal fin. At 88 days after hatching, total length was $26.2-25.7 \mathrm{~mm}$ (mean $25.9 \pm 0.35 \mathrm{~mm}$ ), and scales were formed throughout the body. The fin rays of each part were iii.7 in dorsal fin and iii.6 in anal fin, and finally the external form was the same as the adult fish.
\end{abstract}

Key words : Coreoleuciscus splendidus, Egg, Juvenile, Korean shinner, Larvae

\section{INTRODUCTION}

Gobioninae, which is known for the biggest subfamily among fish of Cypriniformes, Cyprinidae, is small size freshwater fish found in Northeast Asia, and 7 genus, 33 species inhabit in Korea (Kim et al., 2005). Regarding Coreoleuciscus splendidus of Coreoleuciscus, one species had been found. However, but recently between the west Korea subdistrict populations and the south Korea subdistrict populations has been separated to have genetic and morphological differences by Song \& Bang (2015). The entity is scientific named $C$. aeruginos, as a new species distributed in the South Korea Subdistrict populations. There have been numerous studies on $C$. splendidus including taxonomic researches such as fine distribution (Choi et al., 1990), systematology (Kim \& Kang, 1990), genetic variation analysis (Song \& Bang, 2009; Song et al., 2010), spermatogenic and oogenesis process (Kim et al., 2009; Kim et al., 2010), skeletology (Park \& Park, 2012), egg membrane cell and cytogenetics (Kim et al., 2007; Kim et al., 2014), crossbreed hybrid distiction (Song et al., 2017a), and sexual dimorphism and gonad (Song et al., 2017b). Studies on initial life history of P. esocinus include Pseudopugtungia nigra (Kim et al., 1991; Lee et al., 2004), Pungtungia herzi (Baba, 1994; Lee et al., 2002), P. parva (Han et al., 2001) and Sarcocheilichthys nigripinnis morii (Kang et al., 2007). Studies on initial life history of $C$. splendidus are the records of hatching time and hatching size done by Song

Manuscript received May 10, 2019, Received in revised form May 24, 2019, Accepted June 8, 2019

${ }^{\dagger}$ Corresponding Author : Kyeong-Ho Han, Marine Technology Undergraduate, Chonnam National University, Yeosu 59626, Korea. Tel: +82-61-6597163, Fax: +82-61-659-7169, E-mail: aqua05@jnu.ac.kr

This is an Open Access article distributed under the terms of the Creative Commons Attribution Non-Commercial License (http:// creative-commons.org/licenses/by-nc/3.0) which permits unrestricted non-commercial use, distribution, and reproduction in any medium, provided the original work is properly cited. 
(1977) and the observation of egges and advanced fry of $C$. splendidus inhabiting in Chogangcheon of the Geum-River by Han et al. (2018). The Ungcheon-stream, which is the place where broodstork were sampling, is an independent one that is not connected with other water systems, and it is intended to be used for phylogenetic systematic research after the characteristics of its initial life history appearing in each water system's entities are compared with related species.

\section{MATERIALS AND METHODS}

\section{Gathering broodstork fish}

Fro broodstork fish, we caught 20 by using skimming nets at the Ungcheon-stream in Boryeong-si, Chungcheongnam-do in April of 2018 and them to the laboratory packing them with oxygen vinyl. We raised the broodstork in the running water type at a PVC round fish tank (Ø $1.2 \mathrm{~m})$, and maintained $18.0^{\circ} \mathrm{C}-20.0^{\circ} \mathrm{C}$ (average $19.0^{\circ} \mathrm{C}$ ) of the water temperature. We fed frozen blood warms (Hikari, Japan) twice a day.

\section{Induction of ovulation and maintenance of ferti-} lized eggs

Female fish that were used for induction of ovulation were selected among those with abdominal distension and red gonopore. We injected $0.5 \mathrm{~mL}$ of Ovaprim (Syndel, Canada) per $1 \mathrm{~kg}$ of weight and kept them separately. We maintained $21.0^{\circ} \mathrm{C}$ of water temperature, which is raised by $2.0^{\circ} \mathrm{C}$ from $19.0^{\circ} \mathrm{C}$. We collected eggs by pressing abdomen 12 hours later. For artificial insemination, we mixed sperms with the collected eggs and sterilized physiological saline in Petri dish $(\varnothing 15 \mathrm{~cm})$ and fertilized. The fertilized eggs were washed with clean water twice a day to remove impurities.

\section{Breeding larvae and observing form}

We transferred the hatched larvae to a small plastic tank
$(20 \times 10 \times 10 \mathrm{~cm})$ and maintained average $21.0^{\circ} \mathrm{C}$ of the water temperature. We fed 2-3 Artemia sp. nauplius per mL after egg yolk absorption. We added assorted feed (Tetramin, Germany) from 23 days of hatching. From the 46 days after hatching, we provided assorted feed and frozen blood warms. For observation of morphologic development of larvae, we randomly selected five, anesthetized them with MS-222 (Ethyl 3-aminobenzoate methanesulfonate, Sigma Aldrich Co., St. Louis, USA), filmed with a stereoscopic microscope (Nikon SMZ 18, Japan) and measured the size up to $0.01 \mathrm{~mm}$ using a multipurpose projector (Nikon JP V-12B, Japan).

\section{RESULTS}

1. The size of mature entity and the characteristics of eggs

The mature entity of C. splendidus broodstork is 10.2 $11.1 \mathrm{~cm}$ (average $10.6 \pm 0.63 \mathrm{~cm}, \mathrm{n}=10$ ) of the female's total length and $8.30-9.41 \mathrm{~cm}$ (average $8.85 \pm 0.78 \mathrm{~cm}, \mathrm{n}=10$ ) of the male's total length. The matured eggs are white opaque globular shape, and the surface of the eggs is intensely

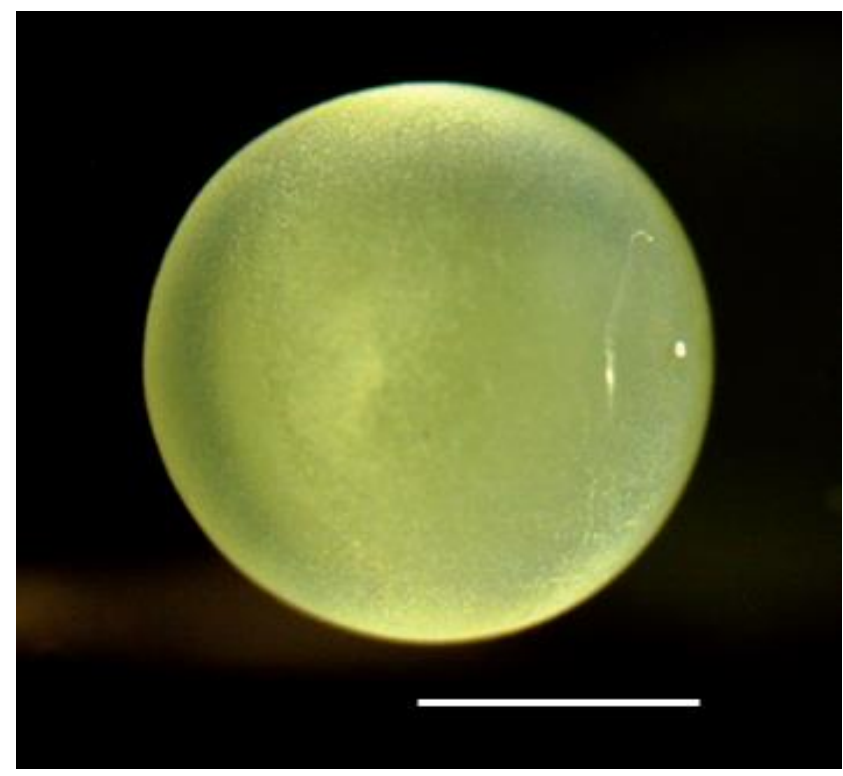

Fig. 1. Morphology of fertilized egg Korean shinner, Coreoleuciscus splendidus. Scale bar $=1.00 \mathrm{~mm}$. 
cohesive (Fig. 1). The number of collected artificially fertilized eggs is $212-424$ (average $318 \pm 149$ eggs), and the sizes of the eggs are 1.86-2.01 mm (average 1.91 \pm 0.14 $\mathrm{mm}, \mathrm{n}=30$ ).

\section{Morphological development of larvae and juveniles}

It took 172 hours and 10 minutes until hatching, and the tail beating to come out breaking the egg membrane. The larvae right after being hatched are $5.27-6.63 \mathrm{~mm}$ of the total length (average $5.95 \pm 0.96 \mathrm{~mm}, \mathrm{n}=10$ ) and have egg yolk on the abdomen. The primordial finfold was from the back to the anus, and some parts of primordial finfold in the front were separated from the anus. The mouth was not open, and the anus was not completely open. There were two pairs of otoliths at the head. The crystalline lens were not developed in the eyes, but pupils were settled, and melanophores were pigmented. The blood circulated back and forth from the heart to the cauda part along the egg yolk and the bottom part of the spinal cord. The anus is $65.3 \%$ of the body length and is located from the center to the back side. The number of myomeres during this period is $30-36$ (Fig. 2A).

The pre-larvae of the 1 days after being hatched were $6.70-6.85 \mathrm{~mm}$ (average $6.77 \pm 0.10 \mathrm{~mm}, \mathrm{n}=10$ ) of total length with a pair of primordial finfolds on the chest and tree branch shape melanophore at the middle part of the body. The dimension of the primordial finfolds became wider compared to those right after being hatched, and the tip of tail at the notochord was developed (Fig. 2B).

The pre-larvae of the 2 days after being hatched were $7.20-7.40 \mathrm{~mm}$ (average $7.30 \pm 0.14 \mathrm{~mm}, \mathrm{n}=10$ ) of total length with the tree branch shape melanophore distributed at the middle part increased to the back of the tail in addition to the upper part of the egg yolk. The shape of digestive canal was a straight line, starting to develop gradually. The respiratory movement was observed with the naked eye due to the development of gill filament at the gill. The mouth started to be divided, but wasn't open completely (Fig. 2C).

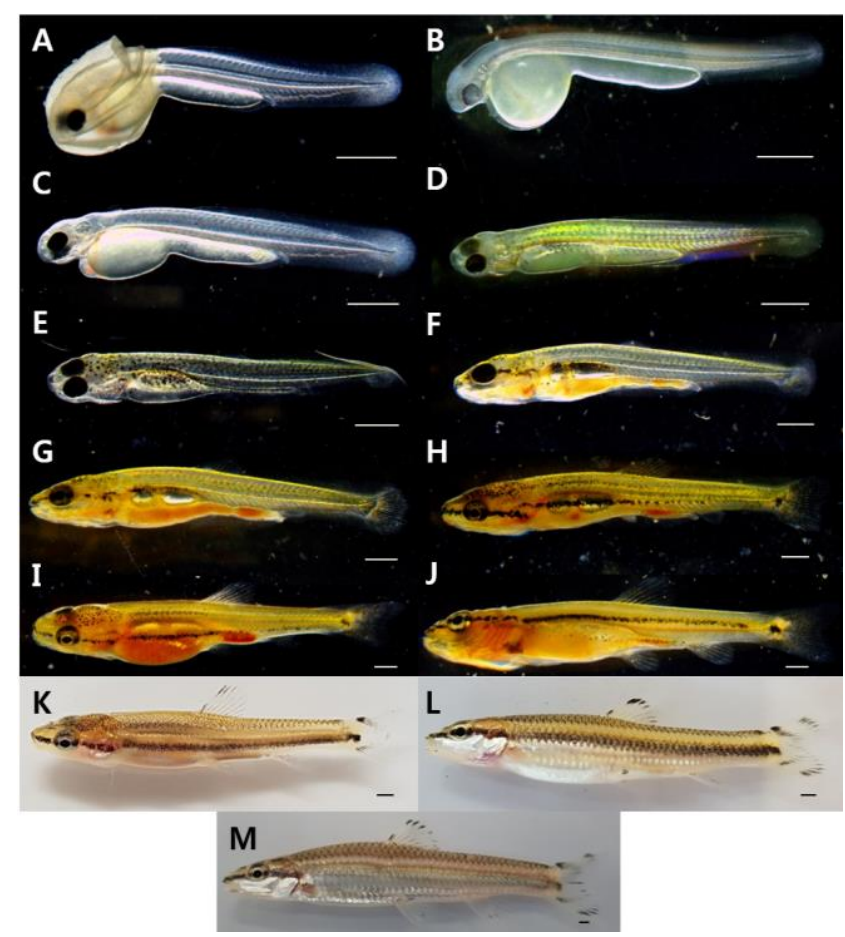

Fig. 2. Morphological of development of larvae and juveniles of Korean shinner, Coreoleuciscus splendidus (Shown in Table 1). Scale bars $=1.00 \mathrm{~mm}$.

The pre-larvae of the 5 days after being hatched were $7.77-7.89 \mathrm{~mm}$ (average $7.79 \pm 0.13 \mathrm{~mm}, \mathrm{n}=10$ ) of total length. The air bladder was formed at the upper part of the egg yolk, enabling fish to start swimming at the middle layer. The tree branch shape melanophore pigmented on the body started to be pigmented widely to the top part of the head, to the gill cover and to the bottom part of the digestive canal. At this period, the fish started to take in prey by opening the mouth, and several small bumps were observed to be formed from the end of the mouth to the end of the tail. Five fin rays were formed at the chest fin, and the pectoral fin ray started to develop at the tip of the tail (Fig. 2D).

The post-larvae of the 10 days after being hatched were $8.44-8.65 \mathrm{~mm}$ (average $8.54 \pm 0.14 \mathrm{~mm}, \mathrm{n}=10$ ) of total length. The air bladder on the upper part of the egg yolk was developed by being divided into two parts, and at the tip of the tail, the fin ray was developed before the spine was bent. The tree branch shape melanophore pigmented 
Table 1. Morphological development of larvae and juveniles of Korean shinner, Coreoleuciscus splendidus

\begin{tabular}{|c|c|c|c|c|}
\hline \multirow{2}{*}{ Stage } & \multirow{2}{*}{ Days } & Total length & \multirow{2}{*}{ Characters } & \multirow{2}{*}{ Fig. 2} \\
\hline & & Mean \pm SD (mm) & & \\
\hline \multirow{4}{*}{ Prelarva } & 0 & $5.95 \pm 0.96$ & 30-36 myotomes; The dorsal fin was formed with membrane fin & A \\
\hline & 1 & $6.77 \pm 0.10$ & A pair of pectoral fins and melanophore were formed & $\mathrm{B}$ \\
\hline & 2 & $7.30 \pm 0.14$ & The digestive tract developed in a straight line & $\mathrm{C}$ \\
\hline & 5 & $7.79 \pm 0.13$ & As the mouth opened, it began to eat live food & $\mathrm{D}$ \\
\hline \multirow{7}{*}{ Postlarva } & 10 & $8.54 \pm 0.14$ & The position of the anus was $72.3 \%$ of the body length & $\mathrm{E}$ \\
\hline & 13 & $9.86 \pm 0.48$ & The vertebrae of the tip of the caudal began to bend & $\mathrm{F}$ \\
\hline & 18 & $11.6 \pm 0.77$ & Development of 7 in the anal fin rays, 22 in the caudal fin rays & G \\
\hline & 23 & $14.3 \pm 0.84$ & All fins were completely separated & $\mathrm{H}$ \\
\hline & 28 & $16.0 \pm 0.91$ & The number of small protrusions formed on the body gradually decreased & I \\
\hline & 33 & $17.6 \pm 0.49$ & The number of stem of the ventral fin rays increased to 7 & $\mathrm{~J}$ \\
\hline & 46 & $21.8 \pm 0.77$ & Scales began to form on the tail & $\mathrm{K}$ \\
\hline \multirow[t]{2}{*}{ Juvenile } & 88 & $25.9 \pm 0.35$ & $\begin{array}{l}\text { The dorsal fin rays was developed in iii. } 7 \text {, and the anal fin rays was de- } \\
\text { veloped in iii. } 6\end{array}$ & - \\
\hline & 139 & $36.8 \pm 2.96$ & The pattern on the fins was similar to that of the adult fish & M \\
\hline
\end{tabular}

on the body was turned into spotted appearance, and at the mouth and the gill cover, melanophore was connected in the line shape. A dorsal fin started to develop, forming five fin rays, and eight fin rays were formed at the caudal fin. The anus during this period was $72.3 \%$ of the body length, being located from the center to the back (Fig. 2E).

The post-larvae of the 13 days after being hatched were 9.52-10.2 $\mathrm{mm}$ (average $9.86 \pm 0.48 \mathrm{~mm}, \mathrm{n}=10$ ) of total length. The number of the dorsal fin rays was increased to 8 , and the tip of spine at the tail were bent by $45^{\circ}$ with hypural developed. The number of the caudal fin rays was increased to 20. The dimension of primordial finfold was gradually decreased, and the back and the tail started to be divided. The fin rays were developed except abdomen and anal fin (Fig. 2F).
The post-larvae of the 18 days after being hatched were 11.1-12.2 mm (average $11.6 \pm 0.77 \mathrm{~mm}, \mathrm{n}=10$ ) of total length. At the anal fin, seven fin rays started to develop, and the number of anal fin rays was increased to 22 . The melanophore pigmented at the mouth and the gill cover was pigmented in the line shape between eyes, and the melanophore distributed at the abdomen above the air bladder became wider to the caudal part (Fig. 2G).

The post-larvae of the 23 days after being hatched were $13.7-14.9 \mathrm{~mm}$ (average $14.3 \pm 0.84 \mathrm{~mm}, \mathrm{n}=10$ ) of total length. The numbers of the dorsal and anal fin rays were increased to 9 and 8 respectively. At the caudal fin, attached stems were formed. As three fin rays were formed at the ventral fin composed of films, all fins were completely divided (Fig. 2H). 
The post-larvae of the 28 days after being hatched were $15.4-16.7 \mathrm{~mm}$ (average $16.0 \pm 0.91 \mathrm{~mm}, \mathrm{n}=10$ ) of total length. The numbers of the anal and ventral fin rays were increased to 9 and 6 respectively. As the caudal fin was divided into two sections, a groove was formed. At the beginning part of caudal fin, melanophore of round spot was pigmented. At the body, the melanophore pigmented in the line shape was connected from the tip of the mouth to the eyes and to the middle part of the caudal peduncle. The number of melanophores was gradually decreased at the abdomen, and some were pigmented around the anus. As the number of the small bumps developed on the body was gradually decreased, the length became short. The anus during this period was $64.1 \%$ of the body length, being located from the right center to the back (Fig. 2I).

The post-larvae of the 33 days after being hatched were $17.3-18.0 \mathrm{~mm}$ (average $17.6 \pm 0.49 \mathrm{~mm}, \mathrm{n}=10$ ) of total length. The number of ventral fin rays was increased to 7 , and the melanophores pigmented at the beginning of the caudal fin were pigmented darkly. The trace of primordial finfolds that remained at each fin completely disappeared (Fig. 2J).

The post-larvae of the 46 days after being hatched were 21.3-22.4 mm (average $21.8 \pm 0.77 \mathrm{~mm}, \mathrm{n}=10$ ) of total length. The melanophore was pigmented in the line shape according to the right center of the body, and at the attached stem above the spot shape melanophores pigmented at the center of the beginning part of the caudal fin, the same spot was pigmented. The melanophores were pigmented at the dorsal, caudal and anal fin rays, and scales were developed at the upper part of the caudal peduncle (Fig. 2K).

The juvenile fish of the 88 days after being hatched were 26.2-25.7 $\mathrm{mm}$ (average 25.9 $\pm 0.35 \mathrm{~mm}, \mathrm{n}=10$ ) of total length. The melanophore was pigmented at each fin ray. The melanophore pigmented at the center of the beginning part of the caudal fin disappeared. Regarding the number of fin rays in each part, the dorsal fin had iii.7 and the anal fin had iii.6, so the number of fin rays and the external shape were developed identically to broodstork (Fig. 2L).

The juvenile fish of the 139 days after being hatched were $34.7-38.9 \mathrm{~mm}$ (average $36.8 \pm 2.96 \mathrm{~mm}, \mathrm{n}=10$ ) of total length. They swim along the water flow established in the rearing aquarium, and their behaviors such as taking in prey were similar to brood stork. The melanophores of line shape formed on the center of the body disappeared, and side lines were formed. The scales formed on the abdomen were silver color, and at the tip of each scale, shadow shape melanophore was formed. The anus during this period $72.5 \%$, and C. splendidus had the anus from the center to the back identically from the moment of being hatched to the juvenile period (Fig. 2M).

\section{DISCUSSION}

Studies on initial life history of fish have been used not only to find out the taxanomic relationships with similar species but also to prove the biological characteristics of species. Many traits revealed during the generation period of fish provide important basic resources for taxanomic relationships of allied species (Blaxter, 1974; Balon, 1985).

Therefore, we compared the sizes of eggs, spawning amounts, hatching time, the sizes of hatched larvae and the periods from post-larvae to juvenile fish in order to identify the taxonomic difference by comparing with the initial life history of fish of gobioninae including fish of $P$. herzi, which has taxonomic relationships. The results are in Table 2.

In the result of comparing the sizes of eggs, eggs of $C$. splendidus inhabiting in the Ungcheon-stream are average 1.86-2.01 mm. Those of Song (1977) were 2.17-2.31 mm, and those in the Chogangcheon stream were $2.11-2.66 \mathrm{~mm}$ (Han et al., 2018), so the sizes in the two studies were similar, but those in the Ungcheon-stream were relatively small, showing difference. There was difference in the sizes of eggs of same species depending on water systems. It seems to be necessary to compare the sizes of eggs in 


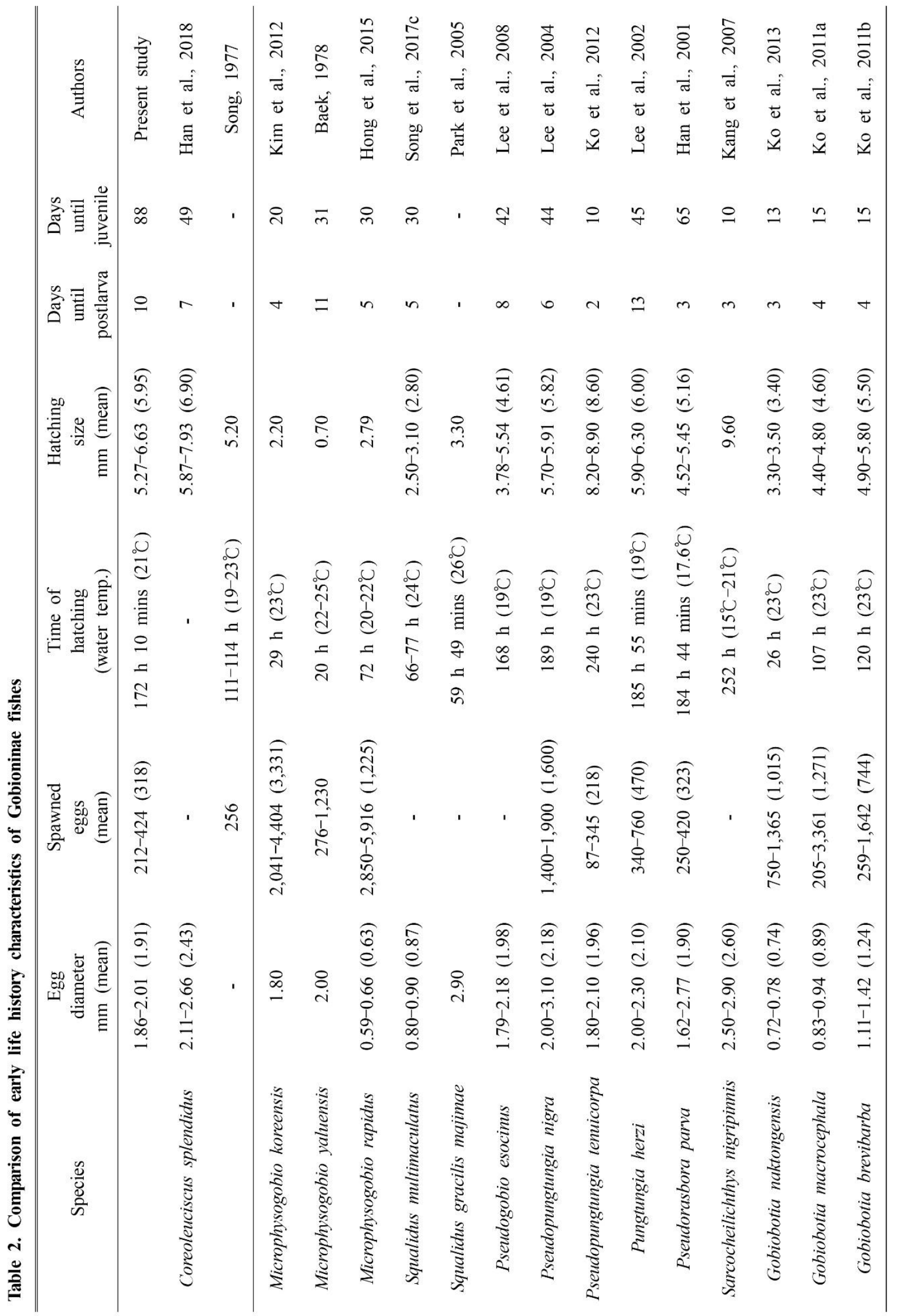


different water systems along with the size of C. aeruginos in the future for more specified research. They were bigger than different fish in the gobioninae including Gobiobotia brevibarba (Ko et al., 2011b), G. macrocephala (Ko et al., 2011a), Microphysogobio koreensis (Kim et al., 2012), M. rapidus (Hong et al., 2015) and G. naktongensis (Ko et al., 2013), and were similar to Pseudogobio esocinus (Lee et al., 2008). They were slightly smaller or similar to M. yaluensis (Baek, 1978), P. nigra (Lee et al., 2004), P. herzi (Lee et al., 2002), S. nigripinnis morii (Kang et al., 2007), Pseudopungtungia tenuicorpa (Ko et al., 2012) and S. gracilis majimae (Park et al., 2005), and were similar to P. parva (Han et al., 2001), which is the same P. herzi family (Table 2).

Regarding the time until hatching, it took 172 hours and 10 minutes for C. splendidus in the Ungcheon-stream to be hatched at $21.0^{\circ} \mathrm{C}$ of water temperature. It took $111-114$ hours for those in the study of Song $(1977)$ at $19^{\circ} \mathrm{C}-23^{\circ} \mathrm{C}$ of water temperature. Because the observation was done when the generation of fertilized eggs started to process, there was difference in the hatching time according to the periods. It took 250 hours for P. tenuicorpa at $23^{\circ} \mathrm{C}, 189$ hours for P. nigra at $19^{\circ} \mathrm{C}, 185$ hours and 55 minutes for $P$. herzi at $19^{\circ} \mathrm{C}, 184$ hours and 44 minutes for P. parva at $17.6^{\circ} \mathrm{C}$ and 252 hours for S. nigripinnis morii at $15^{\circ} \mathrm{C}-$ $21^{\circ} \mathrm{C}$, indicating short period of time until being hatched. It took 120 hours for G. brevibarba at $23^{\circ} \mathrm{C}$, which is long time for hatching, but it took 29 hours for M. koreensis at $23^{\circ} \mathrm{C}, 20$ hours for Microphysogobio yaluensis at $22^{\circ} \mathrm{C}-$ $25^{\circ} \mathrm{C}, 66-77$ hours for S. multimaculatus at $24^{\circ} \mathrm{C}, 59$ hours and 49 minutes for $S$. gracilis majimae at $26^{\circ} \mathrm{C}, 72$ hours for M. rapidus at $21^{\circ} \mathrm{C}$ and 26 hours for G. naktongensis at $23^{\circ} \mathrm{C}$, so they were faster than C. splendidus, and they had relatively fast hatching time among fish of gobioninae.

Water temperature showed a difference between hatching rate and survival rate according to the change. The gilt head bream, Sparus aurata is hatching rate was maximal (91\%-95\%) from 14 to $26^{\circ} \mathrm{C}$. Eggs did not hatch at $12^{\circ} \mathrm{C}$ and $30^{\circ} \mathrm{C}$. Abnormalities at hatching are usual outside the $16^{\circ} \mathrm{C}-22^{\circ} \mathrm{C}$ range. Higher survival at the stage of mouth opening occurred between $16^{\circ} \mathrm{C}$ and $22^{\circ} \mathrm{C}$; outside this range mortality and abnormalities increased considerably. Growth rate and yolk absorption rate increased with increasing temperature (Polo et al., 1991).

Such species that spawn by attaching their eggs to rocks as $P$. tenuicorpa, $P$. nigra, $P$. herzi and $P$. parva had over 180 hours of hatching time. Such species that spawn by spraying their eggs on the floor as G. brevibarba, M. koreensis, M. yaluensis, S. multimaculatus, S. gracilis majimae, M. rapidus and G. naktongensis had less than 120 hours of hatching time. Among related species, S. nigripinnis morii that spawn in the body of freshwater mussels had over 200 hours of hatching time. There is a different tendency of hatching time depending on the spawning habits.

Regarding the sizes of larvae right after being hatched, C. splendidus of the Ungcheon-stream were average 5.95 $\mathrm{mm}$, which is similar to those of the Chogangcheon stream $(5.98-7.07 \mathrm{~mm})$ while they are bigger than those in the study of Song (1977), $5.20 \mathrm{~mm}$. They were smaller than $P$. tenuicorpa $(8.60 \mathrm{~mm}), P$. herzi $(6.0 \mathrm{~mm})$ and $S$. nigripinnis morii $(9.60 \mathrm{~mm})$ but were bigger than $M$. koreensis $(2.20$ $\mathrm{mm})$, M. yaluensis $(0.70 \mathrm{~mm})$, P. esocinus $(4.61 \mathrm{~mm}), G$. macrocephala (4.60 mm), P. nigra (5.82 mm), P. parva (5.16 $\mathrm{mm})$, S. multimaculatus $(2.80 \mathrm{~mm})$, M. rapidus $(2.79 \mathrm{~mm})$, G. naktongensis $(3.40 \mathrm{~mm})$, G. brevibarba $(5.50 \mathrm{~mm})$ and $S$. gracilis majimae $(3.30 \mathrm{~mm})$. There is no similar size to C. splendidus except G. brevibarba among compared related species, so it is possible to distinguish the species from the related species with the size of hatched larvae.

The formation of fish's chromophore is observed after being hatched in case the hatching time is short, but in the fish species that have longer hatching time, it is observed during the egg development process before being hatched (Kim et al., 2012). It took over 100 hours for C. splendidus to be hatched, and melanophores were pigmented on the eyes, but not on the body before being hatched. However, such fish species that have 1-2 days of short hatching time 
as M. yaluensis (Baek, 1978), Cobitis choii (Song et al., 2008) and Koreocobitis naktongensis (Song et al., 2009) aren't known to have melanophores pigmented on the larvae's eyes before being hatched (Song et al., 2017c). In addition, S. multimaculatus, a related species, have 59-67 of relatively short hatching time, but melanophores were pigmented on the eyes at the end of the egg development process. Pseudogobio esocinus, P. nigra, P. herzi, P. parva and G. macrocephala have over 100 hours of long hatching time, and have chromophores pigmented on the eyeballs, the body and the tail before being hatched, but $C$. splendidus have chromophores pigmented only on the eyeballs, so the species are divided into those that have chromophores pigmented on the eyeballs and those that have chromophores pigmented on the body and the tail before being hatched.

The period of each species becoming post-larvae; $C$. splendidus the 10 days after being hatched, M. koreensis the 4 days, S. multimaculatus 5 days, $M$. rapidus 5 days, $P$. esocinus the 8 days, P. tenuicorpa 2 days, P. nigra 6 days, G. macrocephala 4 days, P. parva 3 days, S. nigripinnis morii- 3 days, G. naktongensis 3 days, G. brevibarba 4 days. C. splendidus had slower period than the above species, but faster than P. herzi (13 days) and similar to M. yaluensis (11 days).

Regarding the period of becoming juvenile fish, $C$. splendidus in the Ungcheon-stream were 88 days after being hatched, those in the Chogangcheon stream were 49 days, and those in the study of Song (1977) were 50 days, showing different periods. This might be caused by breeding environments such as water temperature and feed.

The period of becoming juvenile C. splendidus was the slowest among related species such as M. koreensis (20 days), M. yaluensis (31 days), P. esocinus (42 days), P. tenuicorpa (10 days), G. naktongensis (13 days), G. brevibarba (15 days), P. nigra (44 days), P. herzi (45 days), $P$. parva (65 days), S. multimaculatus (30 days) and M. rapidus (30 days).
The periods of becoming post-larvae and juvenile fish were different depending on species, but they can change according to breeding environments such as water temperature and feed, so it is more accurate to breed in the same condition for comparative research.

There are some species that are difficult to observe due to opaque egg membrane among fertilized eggs of $\mathrm{Cy}$ priniformes fish, and in this study, it was difficult to observe the egg development process of $C$. splendidus, and it seems to be necessary to seek the method of removing the opaque egg membrane in order to compare embryological characteristics appearing in the egg development process of $C$. splendidus with related species. As some species were considered as the same species in the past but are divided due to the difference of external forms, coloration and genetic characteristics, there should be continuing comparative studies on the characteristics appearing in entities inhabiting in different water systems and initial life history.

Studies on initial life history are parts of species restoration research, and nowadays, the number of freshwater fish entities is expected to decrease due to habitat degradation including water pollution and river control works. In addition, C. splendidus inhabiting in rapids are gradually losing their habitats due to construction of dammed pools for agricultural irrigation. The species designated as endangered ones among gobioninae fish species are P. nigra, M. koreensis, M. rapidus and G. naktongensis as Class I, along with P. tenuicorpa, G. macrocephala and G. brevibarba as Class II, and they are protected (NIBR, 2018), but the number of endangered species is expected to increase. Therefore, the initial life history of $C$. splendidus can be used as basic resources for taxonomic research and species conservation, and continuing studies seem to be necessary for technology security of reproduction of gobioninae fish.

\section{REFERENCES}

Baba R (1994) Timing of spawning and host-nest choice 
for brood parasitism by the Japanese minnow, Pungtungia herzi, on the Japanese aucha perch, Siniperca kawamebari. Ethology 98:50-59.

Baek YG (1978) On the life history of Microphysogobio yaluensis (Mori). Korean J Ecol Environ 11:43-49.

Balon EK (1985) The theory of saltatory ontogeny and life history models revisited. In: Balon EK (ed), Early Life Histories of Fishes: New Developmental, Ecological and Evolutionary Perspectives. Junk Publishers, Dordrecht, The Netherlands, pp. 13-30.

Blexter JHS (1974) The Early Life History of Fish. SpringVerlag, Berlin, p. 768.

Choi KC, Choi SS, Hong YP (1990) On the microdistribution of fresh water fish, Coleoleuciscus splendidus (Gobioninae) from Korea. Korean J Ichthyol 2:63-76.

Han KH, Lee SH, Seo WI, Yoo DJ, Jin DS, Oh SH, Kim CC (2001) The spawning behavior and early life history of the false dace, Pseudorasbora parva. J Inst Sci Yosu Natl Univ 3:67-76.

Han KH, Nam GW, Lee J, Yu TS, Lee SH (2018) Egg and larval development of Coreoleuciscus splendidus from Korea. Bull Fish Sci Inst Chonnam Natl Univ 26:60-63.

Hong YK, Ko MH, Park SY, Bang IC (2015) Egg development and early life history of the endangered species, Microphysogobio rapidus (Cyprinidae). Korean J Ichthyol 27:86-94.

Kang EJ, Yang H, Lee HH, Kim EO, Kim CH (2007) Characteristics on spawning-host selection and early life history of Sarcocheilichthys nigripinis morii (Pisces, Cyprinidae). Korean J Environ Biol 25:370-377.

Kim CH, Park JS, Kim JG, Park JY (2014) A microscopic study on the egg envelope of an endemic Korean fish, Coreoleuciscus splendidus, cyprinidae, teleostei. Korean Soc Microsc 44:96-99.

Kim CH, Yoon SW, Kim JG, Kim HT, Park JS, Park JY (2012) Embryonic development and early life history of the endangered species Microphysogobio koreensis (Pisces: Cyprinidae). Korean J Ichthyol 24:160-166.
Kim DH, Kim WJ, Teng YC, Kim S, Lee KJ (2010) The Oogenesis of Coreoleuciscus splendidus, cyprinidae, teleostei. Korean J Microsc 40:9-14.

Kim DH, Lee KJ, Kim S, Teng YC (2009) The spermatogenesis of Coreoleuciscus splendidus cyprinidae, teleostei. Korean J Microsc 39:227-236.

Kim DS, Song HY, Bang IC, Nam YK (2007) Cytogenetic analysis of Korean shinner, Coreoleuciscus splendidus (Cyprinidae). J Aquac 20:140-143.

Kim IS, Choi Y, Lee CH, Lee YJ, Kim BJ, Kim JH (2005) Illustrated Book of Korean Fishes. Kyo-Hak, Seoul, pp. 113-125.

Kim IS, Kang KJ (1990) Systematic studies on the skull and superficial cephalic muscles of the cyprinid fish, Coreoleuciscus splendidus Mori (Pisces, Cyprinidae). Korean Soc Syst Zool 6:1-16.

Kim, JK, Hong YP, Ahn KG, Choi SS (1991) Studies on early embryonic development of Pseudopuntungia nigra, Korean endemic species. Korean Soc Limnol 24:129136.

Ko MH, Kim WJ, Park SY, Bang IC (2011a). Egg development and early life history of the endangered species Gobiobotia macrocephala (Pisces: Cyprinidae). Korean J Ichthyol 23:198-205.

Ko MH, Lee IR, Bang IC (2013) Egg development and early life history of endangered species Gobiobotia naktongensis (Pisces: Cyprinidae). Korean J Ichthyol 25:9-16.

Ko MH, Park SY, Bang IC (2012). Egg development and early life history of the slender shinner, Pseudopungtungia tenuicorpa (Pisces: Cyprinidae). Korean J Ichthyol 24:48-55.

Ko MH, Park SY, Lee IR, Bang IC (2011b). Egg development and early life history of the endangered species Gobiobotia brevibarba (Pisces: Cyprinidae). Korean Soc Limnol 44:136-143.

Lee SH, Han KH, Hwang DS (2002) The early life history and spawning behavior of the Puntungia herzi. J Inst 
Sci Yosu Natl Univ 4:115-126.

Lee SH, Han KH, Yoon SM, Hwang DS, Yoo DJ, Lee CL, Kim IS, Son YM (2004) Early life history and spawning behavior of Pseudopuntungia nigra. Korean J Ichthyol 16:309-316.

Lee SH, Oh GN, Kim KS, Oh YS, Kang KW, Hwang JH, Lee BI, Lee WK, Han KH (2008). Embryonic and larval development of goby minnow, Pseudogobio esocinus. Dev Reprod 12:283-288.

NIBR [National Institute of Biological Resources]. 2018. Endangered wild animals and plants. Retrieved December 16, 2018, from https://species.nibr.go.kr/home/ mainHome.do?cont_link $=011 \&$ subMenu $=011011 \&$ con $\mathrm{tCd}=011011$

Park JS, Park JY (2012) A osteology study of Coreoleuciscus splendidus (Cypriniformes; Cyprinidae), Korea. Korean J Ichthyol 24:253-262.

Park K, Hong Y, Moon W, Choi S, An KG (2005) The egg development of Korean slender gudgeon, Squalidus gracilis majimae (Cypriniforms: Cyprinidae). Korean J Limnol 381:73-82.

Polo A, Yufera M, Pascual E (1991) Effects of temperature on egg and larval development of Sparus aurata L. Aquaculture 92:367-375.

Song HH (1977) Studies on the spawning and early development of Coreoleuciscus splendidus Mori. J Sci Edu (Jeonju National University of Education) 3:49-60.

Song HY, Bang IC (2009) Genetic variation of Coreoleuciscus splendidus populations from four major rivers in Korea as assessed by RAPD PCR. Korean J Ichthyol
21:129-133.

Song HY, Bang IC (2015) Coreoleuciscus aeruginos (Teleostei: Cypriniformes: Cyprinidae), a new species from the Seomjin and Nakdong rivers, Korea. Zootaxa 3931: 140-150.

Song HY, Kim JH, Seo IY, Bang IC (2017a) Species and hybrid identification of Genus Coreoleuciscus species in hwnag-ji stream, nakdong river basin in Korea. Korean J Ichthyol 29:1-12.

Song HY, Kim KM, Shin AR, Lee JS, Park HW, Lee WO (2017b) Analysis of gonadosomatic index (GSI) and sexual dimorphism of Coreoleuciscus splendidus in age groups. Korean J Ichthyol 29:176-189.

Song HY, Kim KY, Yoon MG, Nam YK, Kim DS, Bang IC (2010) Genetic variation of Coreoleuciscus splendidus populations (Teleostei; Cypriniformes) from four major river drainage systems in south Korea as assessed by AFLP markers. Genes Genom 32:199-205.

Song HY, Kim WJ, Lee WO, Bang IC (2008) Morphological development of egg and larvae of Iksookimia choii (Cobitidae). Korean J Limnol 41:104-110.

Song HY, Ko MH, Seo IY, Moon SJ, Bang IC (2017c) Morphological development of egg and larvae of Squalidus multimaculatus (Gobioninae). Korean J Ichthyol 29:52-61.

Song HY, Yang H, Jo EM, Sin HC, Bang IC (2009) Morphological development of egg and larvae of Koreocobitis nakdongensis (Cobitidae). Korean J Ichthyol 21: 247-252. 